\section{Selection of common cashew tree genotypes in commercial growing areas in municipalities of Piauí, Brazil}

\author{
Carlos Humberto Aires Matos Filho ${ }^{1}$, José Airton Rodrigues \\ Nunes $^{2 *}$, Ângela Celis de Almeida Lopes ${ }^{1}$ and Regina Lucia \\ Ferreira Gomes ${ }^{1}$
}

\begin{abstract}
The aim of this study was to estimate genetic parameters and to select promising common cashew tree genotypes in commercial growing areas in four environments in Piauí (Piracuruca - P, Barro Duro - B, Teresina - T, and Ipiranga do Piaui - I) using the mixed model approach. Genetic variances were significant for most of agromorphological and physicochemical traits of the cashew nut and accessory fruit. The physicochemical traits exhibited more genetic variability and less environmental influence. The genetic correlations among traits were significant, positive, and of medium to high magnitude, except for titratable acidity and total soluble solids. The prominent genotypes for the agromorphological traits were 115(I), 110(I), 92(T), 38(P), 108(I), and 103(I); for titratable acidity, 31(P), 118(I), and 74(B); for total soluble solids, 124(I) and 112(I); and for total soluble solids/titratable acidity, $109(I)$ and $47(P)$. The selected genotype 115(I) exhibited superior performance for most of the traits.
\end{abstract}

Keywords: Anacardium occidentale, cashew nut, BLUP, heritability, correlation.

\section{INTRODUCTION}

Many native and exotic fruit-bearing species have been commercially grown in Brazil. A notable example is the cashew tree (Anacardium occidentale L.), whose main product is the cashew nut. The kernel of the cashew nut has high nutritional and economic value, and it is readily marketable both domestically and internationally. It is an important currency-generating commodity (Barros et al. 1999).

Nevertheless, even with this economic importance for the Brazilian trade balance, cashew orchards are low yielding and not competitive. Low yield has many causes, such as the use of unimproved clones, the age of the orchards (Guanziroli et al. 2009), drought periods, the formation and incentives for growing common cashew tree genetic material originating from seeds, which generates a great deal of heterogeneity, and lack of adoption of agricultural practices with fertilization, soil amendment, and weed control.

Due to the allogamous reproductive system, there is a high level of heterogeneity in cashew populations (Barros 1999). Common cashew tree orchards originating from seeds have high variability and, probably, adaptability that can be used for selection. Therefore, these areas have notable strategic value for plant breeding for the purpose of identifying superior genotypes.
Crop Breeding and Applied Biotechnology 19(3), 245-252, 2019 Brazilian Society of Plant Breeding. Printed in Brazil http://dx.doi.org/10.1590/198470332019v19n3a35 
However, this identification requires the use of statistical methods that can more adequately deal with situations of imbalance, absence of formal experimental design, and heterogeneity of genetic variances expressed in the populations. In this regard, the mixed model approach that was formally presented and developed by Charles Roy Henderson and other researchers constitutes an option as a robust statistical selection method (Resende 2002).

The mixed model approach is widely used in animal genetic evaluation and has progressively expanded in breeding of plant species with different reproductive systems (allogamous, autogamous, and mixed system), and notably for perennial crops (forest or fruit-bearing species) (Paiva et al. 2002, Santos et al. 2014). The use of this approach has been reported in cashew tree growing (Cavalcanti et al. 2007, Maia et al. 2009, Silva et al. 2012, Silva et al. 2013); nevertheless, the scenario of selection of clones or genotypes from populations in commercial growing areas has not been considered.

Considering this situation, the aim of this study was to estimate genetic parameters and to select promising genotypes of common cashew trees in commercial growing areas of the state of Piauí using the mixed model approach for agromorphological and physicochemical traits of the cashew nut and pseudofruit/accessory fruit.

\section{MATERIAL AND METHODS}

The study was conducted in four growing environments characterized by commercial growing areas of common cashew trees in the municipalities of Piracuruca, Barro Duro, Teresina, and Ipiranga do Piauí in the state of Piauí, Brazil (Table 1). There was not a specific experimental design for all areas. The Köppen climate classification of the areas studied is Aw, with a summer rainy season.

The common cashew tree plants of these areas were derived from planting of cashew nuts, which makes genetic variability possible. To obtain data, plants were randomly sampled that produced fruits in the months of September and October 2015. These samples were georeferenced, identified, and codified by letters symbolizing the place of origin or municipality, followed by a number. Ten fruits and accessory fruits were taken at random from each plant. Most of the orchards do not have a defined space between plants, and crop treatments are confined to weed control through clearing of weeds around the harvest areas.

Biometric evaluation of the cashew trees was performed based on the following agromorphological traits, selected from the list of cashew descriptors published by the IBPGR (1986), currently known as Biodiversity International: total weight (TW), in reference to the fruit and accessory fruit, accessory fruit weight (AFW), fruit weight (FW), fruit length $(\mathrm{FL})$, fruit width (FWd), fruit thickness (FT), kernel weight (KW), kernel length (KL), kernel width (KWd), kernel thickness $(\mathrm{KT})$, accessory fruit length (AFL), apical diameter of the accessory fruit (ADAF), and basal diameter of the accessory fruit (BDAF). The following physicochemical traits were evaluated: titratable acidity (TA), total soluble solids (TSS), and soluble solids and titratable acidity ratio (TSS/TA).

Fruits, accessory fruits, and kernels were measured in ten fruits per plant with the aid of an analytical balance and digital caliper rule; the weights were recorded in grams and the lengths, widths, and thicknesses in millimeters. Total soluble solids were determined with the aid of a benchtop refractometer and expressed in the Brix scale, and titratable acidity was expressed in \% of organic acids according to the methodology of the Instituto Adolfo Lutz (2008), these being determined from the juice collected of the ten selected accessory fruits.

Statistical analyses were performed according to the following mixed linear model:

$y=X b+Z g+e$,

where: $y$ is the vector of phenotypic observations; $X$ is the incidence matrix of fixed effects; $b$ is the vector of fixed effects (intercept and growing environments Piracuruca (P), Barro Duro (B), Teresina (T), and Ipiranga do Piauí (I));

Table 1. Geographic coordinates, altitude, number of plants sampled, and soil textural class of the growing environments in some municipalities of Piauí, Brazil

\begin{tabular}{|c|c|c|c|c|c|c|}
\hline \multirow{2}{*}{ Municipality } & \multirow{2}{*}{ Latitude } & \multirow{2}{*}{ Longitude } & \multirow{2}{*}{$\begin{array}{l}\text { Altitude } \\
\text { (m) }\end{array}$} & \multirow{2}{*}{$\begin{array}{l}\text { No. of } \\
\text { plants }\end{array}$} & \multicolumn{2}{|l|}{ Texture of soil } \\
\hline & & & & & $0-20 \mathrm{~cm}$ & $20-40 \mathrm{~cm}$ \\
\hline Piracuruca (P) & 3o $55^{\prime} 41^{\prime \prime} \mathrm{S}$ & $41042^{\prime} 33^{\prime \prime} \mathrm{W}$ & 60 & 50 & Sandy & Sandy \\
\hline Barro Duro (B) & 5o $49^{\prime} 01^{\prime \prime} \mathrm{S}$ & $42 \circ 30^{\prime} 47^{\prime \prime} \mathrm{W}$ & 200 & 34 & Clayey & Very clayey \\
\hline Teresina $(T)$ & $5^{\circ} 05^{\prime} 20^{\prime \prime} \mathrm{S}$ & $42^{\circ} 48^{\prime} 7^{\prime \prime} \mathrm{W}$ & 72 & 16 & Sandy clay loam & Sandy clay loam \\
\hline Ipiranga do Piauí (I) & $6^{\circ} 49^{\prime} 47^{\prime \prime} \mathrm{S}$ & $41^{\circ} 44^{\prime} 29^{\prime \prime} \mathrm{W}$ & 410 & 25 & Sandy clay loam & Sandy clay loam \\
\hline
\end{tabular}


$Z$ is the incidence matrix of random effects; and $g$ is the vector of random effects of the plants or genotypes, with $\mathrm{g} \sim \operatorname{NMV}(0, G)$. A heteroscedastic covariance structure was assumed for the matrix $\mathrm{G}$ as follows:

$$
G=\left|\begin{array}{cccc}
\mathrm{I}_{(50)} \sigma_{e(\mathrm{P})}^{2} & 0 & 0 & 0 \\
0 & \mathrm{I}_{(34)} \sigma_{e(\mathrm{~B})}^{2} & 0 & 0 \\
0 & 0 & \mathrm{I}_{(16)} \sigma_{e(\mathrm{~T})}^{2} & 0 \\
0 & 0 & 0 & \mathrm{I}_{(25)} \sigma_{e(1)}^{2}
\end{array}\right|
$$

$e$ is the vector of the error random effects, with $e \sim N M V\left(0, / \sigma_{e}^{2}\right)$.

The variance components were estimated by the restricted maximum likelihood (REML) method. The significance of these components was evaluated by the Wald test, at 5\% probability (Wald 1943). The linear mixed model was fitted, and the BLUE (best linear unbiased estimator) of the fixed effects and BLUP (best linear unbiased prediction) of the genotypic values was obtained using Proc Mixed of SAS/STAT software (Littell et al. 2006). The accuracies of the BLUP $\left(r_{\hat{g} g}\right)$ predictions and the heritability for selection at the plant level were also estimated (Resende 2002).

The association between traits was checked by estimation of genetic correlation, whose significance was tested using the non-parametric bootstrap method, assisted by the software Genes (Cruz 2013). Genetic gain was estimated from the mean of the BLUP of the genotypic values of the selected plants. The adjusted means of the growing environments were also compared by the Tukey-Kramer test (SAS 2008).

\section{RESULTS AND DISCUSSION}

The genetic variances among plants for the traits evaluated in the four environments were significant $(P<0.05)$ by the Wald test, except for kernel weight in the Barro Duro growing area (Table 2). Heterogeneity of the genetic variances

Table 2. Genetic variance $\left(\sigma_{g}^{2}\right)$, selective accuracy $\left(r_{\hat{g} g}\right)$, heritability $\left(h^{2}\right)$, residual variance $(e)$, and mean for the traits total weight (TW), accessory fruit weight (AFW), fruit weight (FW), fruit length (FL), fruit width (FWd), fruit thickness (FT), kernel weight (KW), kernel length (KL), kernel width (KWd), kernel thickness (KT), accessory fruit length (AFL), basal diameter of the accessory fruit (BDAF), apical diameter of the accessory fruit (ADAF), titratable acidity (TA), total soluble solids (TSS), and total soluble solids and titratable acidity ratio (TSS/TA), evaluated in 125 genotypes of common cashew tree in growing environments in some municipalities of Piauí state, Brazil

\begin{tabular}{|c|c|c|c|c|c|c|c|c|c|c|c|c|c|c|}
\hline \multirow{2}{*}{ Trait } & \multicolumn{3}{|c|}{ Piracuruca } & \multicolumn{3}{|c|}{ Barro Duro } & \multicolumn{3}{|c|}{ Teresina } & \multicolumn{3}{|c|}{ Ipiranga do Piauí } & \multirow[b]{2}{*}{$\sigma_{g}^{2}$} & \multirow{2}{*}{ Mean } \\
\hline & $\sigma_{g}^{2}$ & $r_{\hat{g} g}$ & $h^{2}$ & $\sigma_{g}^{2}$ & $r_{\hat{g} g}$ & $h^{2}$ & $\sigma_{g}^{2}$ & $r_{\hat{g} g}$ & $h^{2}$ & $\sigma_{g}^{2}$ & $r_{\hat{g} g}$ & $h^{2}$ & & \\
\hline TW & $575.76^{*}$ & 0.96 & 0.65 & $478.59 *$ & 0.95 & 0.61 & $896.14^{*}$ & 0.95 & 0.74 & $1242.49 *$ & 0.96 & 0.80 & 310.97 & 72.72 \\
\hline AFW & $498.51^{*}$ & 0.96 & 0.61 & $425.93^{*}$ & 0.95 & 0.58 & $800.73^{*}$ & 0.95 & 0.72 & $1100.77^{*}$ & 0.96 & 0.78 & 312.22 & 65.35 \\
\hline FW & $4.87^{*}$ & 0.98 & 0.83 & $2.83^{*}$ & 0.97 & 0.75 & $4.97^{*}$ & 0.96 & 0.84 & $6.00 *$ & 0.97 & 0.86 & 0.96 & 7.33 \\
\hline FT & $2.70^{*}$ & 0.95 & 0.57 & $3.01^{*}$ & 0.95 & 0.60 & $2.21^{*}$ & 0.93 & 0.52 & $4.14 *$ & 0.95 & 0.67 & 2.04 & 16.79 \\
\hline KW & $0.36^{*}$ & 0.87 & 0.23 & $0.04^{\text {n.s }}$ & 0.53 & 0.03 & $0.24 *$ & 0.79 & 0.17 & $0.20 *$ & 0.75 & 0.14 & 1.20 & 2.11 \\
\hline KL & $11.57^{*}$ & 0.97 & 0.64 & $4.37^{*}$ & 0.92 & 0.40 & $14.27^{*}$ & 0.95 & 0.69 & $16.21^{*}$ & 0.95 & 0.72 & 6.42 & 27.14 \\
\hline BDAF & $29.47 *$ & 0.95 & 0.55 & $30.37^{*}$ & 0.94 & 0.55 & $22.57^{*}$ & 0.92 & 0.48 & $67.19^{*}$ & 0.95 & 0.73 & 24.32 & 44.23 \\
\hline ADAF & $16.06^{*}$ & 0.91 & 0.38 & $27.63^{*}$ & 0.94 & 0.52 & $18.47^{*}$ & 0.91 & 0.42 & $46.03^{*}$ & 0.94 & 0.64 & 25.61 & 31.92 \\
\hline TA & $0.07^{*}$ & 0.98 & 0.99 & $0.03 *$ & 0.97 & 0.97 & $0.004^{*}$ & 0.91 & 0.80 & $0.14 *$ & 0.98 & 0.99 & 0.001 & 0.49 \\
\hline TSS & $2.29 *$ & 0.99 & 0.98 & $1.88^{*}$ & 0.98 & 0.97 & $1.57^{*}$ & 0.96 & 0.97 & $4.33^{*}$ & 0.98 & 0.99 & 0.05 & 13.77 \\
\hline TSS/TA & $109.88 *$ & 0.97 & 0.91 & $89.00 *$ & 0.97 & 0.89 & $124.16^{*}$ & 0.95 & 0.92 & $196.76^{*}$ & 0.97 & 0.95 & 10.54 & 34.36 \\
\hline
\end{tabular}

\footnotetext{
* Significant at $5 \%$ probability by the Wald test.
} 
among the growing environments was also observed, especially for Ipiranga do Piauí, whose variances had the highest magnitude. This indicates the existence of genetic variability in the populations, which is fundamental for the practice of selection and must be related to the allogamous reproductive system and the formation of cashew orchards through seeds (Barros et al. 1999).

The selection of common cashew tree genotypes with good characteristics can assist breeding programs that aim at exploiting heterosis. In an experiment to evaluate the combination between the early dwarf and common cashew tree commercial clones, Cavalcanti et al. (2000) measured plant height, canopy diameter, number of nuts per plant, nut yield, mean nut weight, mean kernel weight, and kernel weight/nut weight ratio and found the presence of heterosis. These authors emphasized that some traits, such as the quality and weight of the nut and kernel, require genetic advances and that the narrow genetic base used in breeding of the crop characterizes a situation of genetic vulnerability. They found that the use of superior genotypes obtained by hybridization between early dwarf and common cashew constitutes an important strategy for cashew tree breeding, and it may be useful for increasing the genetic variability of the crop. This result was confirmed in another study conducted by the same authors (Cavalcanti et al. 2007).

The efficiency of selection depends on how heritable the trait in question is. The titratable acid, total soluble solids, and total soluble solids/titratable acidity ratio traits exhibited more genetic variability and were less influenced by the environment $\left(h^{2}>0.80\right)$ than the others.

For fruit width, length, and weight, the heritabilities ranged from 0.70 to 0.86 . Fruit thickness exhibited the lowest values estimated ( 0.52 to 0.67$)$ in regard to nut morphology. For accessory fruit, length was prominent, with heritability values that ranged from 0.76 to 0.86 .

In studies evaluating intensive early selection, which consists of plant densities higher than traditional practices, Cavalcanti and Resende (2010) report that early selection was carried out for traits of high heritability, such as mean fruit weight, in the first two years of age of the plants, and the efficiency and feasibility of the method were observed. In this context, the genotypes evaluated could be exploited, both for heterosis and for intensive early selection in the traits measured with high values of heritability.

In the main product of the crop, the kernel, the estimates of heritability were higher in regard to length and width, and of lower magnitude for thickness $\left(h^{2}<0.48\right)$. Kernel weight exhibited low values of heritability in all environments, indicating low genetic variability for this trait in the populations. According to Cavalcanti et al. (2007), high values of heritability for kernel weight and fruit weight in cashew trees indicate greater chance of the occurrence of a small number of genes or lower environmental effect influencing the traits in question. Cavalcanti et al. (2012) detected three QTL candidates associated with cashew nut weight from a cross between cashew tree clones CCP 1001 (hybrid dwarf $x$ common) and CP 96 (dwarf).

It is noteworthy that heritability is not immutable, but is influenced by the trait evaluated, the population and environmental conditions in which the populations are subjected, the experimental unit, the size of the sample, and accuracy in collection of the data. Heritability can be defined as the expression of confidence of the phenotypic value as a guide of genetic value (Falconer 1981).

The values of selective accuracy indicate that the class of precision of the experiment was generally high. Selective accuracy refers to the correlation between the true genetic value and the estimated or predicted value, which require the existence of genetic variation for estimation. The nearer accuracy is to 1 , the lower the deviations between the parametric and the estimated genetic values, accentuating the reliability of selection (Henderson 1984, Resende 2007). In this study, the information extracted from the data presented high reliability for describing the genetic values of the cashew trees evaluated, according to Resende and Duarte (2007) even though the data came from commercial plants, with no experimental design and data of only one year.

In general, there was lower relative precision for fruit traits, especially fruit weight. In this case, the low accuracy is linked to the lower magnitude of genetic variation observed in the growing environments. For the traits that exhibited significant genetic variance, low values of prediction error variance (PEV) were observed, indicating that residual or environmental variance was small or of low magnitude; that is, low prediction errors lead to high accuracy and, according to Santos et al. (2014), this situation is favorable for selection of superior individuals.

From BLUP predictions of the genotypic values of the 125 individuals sampled, the genotypic correlation coefficients were estimated among the 14 quantitative traits (Table 3). Most of the correlation estimates were significant, positive, and of medium to high magnitude $(\geq 0.40$ ), except for titratable acidity and total soluble solids, which exhibited negative, 
non-significant, and low values $(<-0.40)$ with the other traits, and they were non-significant between themselves. Titratable acidity and total soluble solids are influenced by the environment, and the peduncle maturation stage is one of the factors of variation.

The selection of genotypes with desirable fruit, accessory fruit, and kernel traits is facilitated by the presence of positive and significant genetic correlations among these traits, and indirect selection can be carried out by means of easily measured descriptors (Cruz et al. 2004). In addition, there should not be difficulty in selecting individuals with satisfactory concentrations of titratable acidity, total soluble solids, and total soluble solids/acidity ratio, with desirable fruit, accessory fruit, and kernel traits, considering that the genetic correlation estimates were non-significant and of low magnitude, although negative (Table 3). Difficulties for joining desirable phenotypes for nut and accessory fruit traits were reported by Paiva et al. (2005).

Differences were found between the growing environments studies in regard to mean performance of the plants for most of the traits evaluated, except for total weight, fruit thickness, kernel thickness, and accessory fruit length (Table 4). Piracuruca was among the municipalities with higher mean values for most of the descriptors evaluated, except for accessory fruit weight, apical and basal diameter of the accessory fruit, and total soluble solids/titratable acidity ratio.

The TSS/TA ratio exhibited the greatest phenotypic effect in Teresina. The estimate of this ratio was mainly influenced by titratable acidity, which was lower in Teresina. In Piracuruca and Ipiranga do Piauí, high acidity reduced the value of the TSS/TA ratio. This ratio is indicative of the balance between the sweet and acid flavor of the fruit, and is considered an important index of fruit maturity (Lima et al. 2007). It is a better indicator of flavor, especially for in natura consumption of the accessory fruit, than isolated analysis of soluble solids concentration and acidity. According to Alves et al. (1999), maximum eating quality is reached when the accessory fruit is completely mature, coinciding with high TSS/TA ratio.

The Piracuruca and Ipiranga do Piauí environments contrasted for the fruit and kernel traits; the greatest estimates were obtained in the first environment. This may have stemmed from selection of individuals made by producers; the selection is more directed to nut sales in Piracuruca and production of preserves and cajuína (a cashew juice beverage) in Ipiranga do Piauí.

The results found reinforce the existence of genetic variability and the possibility of capitalizing on the beneficial effects of selection practiced by producers. This information becomes important to the extent that problems stemming from genetic vulnerability in growing areas with caju clones have been reported (Rabbani et al. 2012), mainly as a consequence of the use of a small variety of clones, especially of CCP-76 and CCP-09, with a narrow genetic base,

Table 3. Estimates of genetic correlations between the traits total weight (TW), accessory fruit weight (AFW), fruit weight (FW), fruit length (FL), fruit width (FWd), fruit thickness (FT), kernel weight (KW), kernel length (KL), kernel width (KWd), kernel thickness (KT), accessory fruit length (AFL), basal diameter of the accessory fruit (BDAF), apical diameter of the accessory fruit (ADAF), titratable acidity (TA), total soluble solids (TSS), and total soluble solids and titratable acidity ratio (TSS/TA), evaluated in 125 genotypes of common cashew tree in growing environments in Piracuruca, Barro Duro, Teresina, and Ipiranga do Piauí, PI, Brazil

\begin{tabular}{|c|c|c|c|c|c|c|c|c|c|c|c|c|c|c|c|}
\hline Trait & AFW & FW & $\mathrm{FL}$ & FWd & FT & KW & KL & KWd & KT & AFL & BDAF & ADAF & TA & TSS & TSS/TA \\
\hline TW & $0.99 * *$ & $0.77^{* *}$ & $0.70 * *$ & $0.72 * *$ & $0.55^{* *}$ & $0.59 * *$ & $0.72 * *$ & $0.67 * *$ & $0.46^{* *}$ & $0.76 * *$ & $0.88^{* *}$ & $0.58^{* *}$ & $-0.22^{*}$ & $-0.28 * *$ & 0.08 \\
\hline AFW & & $0.73^{* *}$ & $0.67^{* *}$ & $0.69 * *$ & $0.52 * *$ & $0.57^{* *}$ & $0.69 * *$ & $0.64 * *$ & $0.44 * *$ & $0.76 * *$ & $0.88^{* *}$ & $0.58 * *$ & $-0.21^{*}$ & $-0.27 * *$ & 0.09 \\
\hline FW & & & $0.90 * *$ & $0.94 * *$ & $0.71 * *$ & $0.69 * *$ & $0.89 * *$ & $0.83 * *$ & $0.53^{* *}$ & $0.63 * *$ & $0.64 * *$ & $0.43^{* *}$ & -0.15 & $-0.18^{*}$ & 0.01 \\
\hline $\mathrm{FL}$ & & & & $0.94^{*}$ & $0.49 * *$ & $0.59 * *$ & $0.85^{* *}$ & $0.78^{* *}$ & $0.30 * *$ & $0.67 * *$ & $0.58^{* *}$ & $0.31 * *$ & -0.12 & $-0.18^{*}$ & -0.05 \\
\hline FWd & & & & & $0.61^{* *}$ & $0.62 * *$ & $0.85^{* *}$ & $0.81 * *$ & $0.41 * *$ & $0.62 * *$ & $0.62^{* *}$ & $0.38^{* *}$ & -0.13 & $-0.20^{*}$ & -0.05 \\
\hline $\mathrm{FT}$ & & & & & & $0.59 * *$ & $0.55^{* *}$ & $0.47 * *$ & $0.80 * *$ & $0.36 * *$ & $0.50 * *$ & $0.39 * *$ & $-0.26 * *$ & -0.16 & 0.06 \\
\hline KWd & & & & & & & & & $0.48^{* *}$ & $0.57 * *$ & $0.55^{* *}$ & $0.39 * *$ & $-0.18^{*}$ & $-0.30 * *$ & 0.03 \\
\hline KT & & & & & & & & & & $0.25 * *$ & $0.44 * *$ & $0.40 * *$ & $-0.32 * *$ & $-0.20 *$ & 0.13 \\
\hline AFL & & & & & & & & & & & $0.54^{* *}$ & 0.12 & $-0.21 *$ & $-0.23 *$ & 0.01 \\
\hline BDAF & & & & & & & & & & & & $0.73 * *$ & $-0.23 * *$ & $-0.29 * *$ & 0.01 \\
\hline ADAF & & & & & & & & & & & & & $-0.25 * *$ & $-0.21 *$ & 0.14 \\
\hline
\end{tabular}

** and * significant at $1 \%$ and at $5 \%$ probability, respectively, by the bootstrap method. 
because they originated from prospection and research of the Pacajus experimental station in the coastal region of the coastal-caatinga transition area.

The greatest gains from selection of the first individuals selected were for total weight, accessory fruit weight, and titratable acidity. In these, the values of gains from selection exceed the mean values of the populations. For most of the descriptors, the gains are high, as, for example, for kernel weight, with a mean of $2.11 \mathrm{~g}$ and gain of $1.87 \mathrm{~g}$ with the selection of individual 32 (Table 5).

Table 4. Comparison among the means of the growing environments in Piracuruca, Barro Duro, Teresina, and Ipiranga do Piauí, PI, for the traits total weight (TW), accessory fruit weight (AFW), fruit weight (FW), fruit length (FL), fruit width (FWd), fruit thickness $(\mathrm{FT})$, kernel weight $(\mathrm{KW})$, kernel length $(\mathrm{KL})$, kernel width (KWd), kernel thickness $(\mathrm{KT})$, accessory fruit length (AFL), basal diameter of the accessory fruit (BDAF), apical diameter of the accessory fruit (ADAF), titratable acidity (TA), total soluble solids (TSS), and total soluble solids and titratable acidity ratio (TSS/TA), evaluated in 125 genotypes of common cashew tree in 2015

\begin{tabular}{|c|c|c|c|c|}
\hline Trait & Piracuruca & Barro Duro & Teresina & Ipiranga do Piauí \\
\hline TW & $67.75 a$ & $77.49 \mathrm{a}$ & $85.95 \mathrm{a}$ & $66.66 \mathrm{a}$ \\
\hline AFW & $59.74 \mathrm{~b}$ & $70.29 a$ & $78.48 \mathrm{a}$ & $60.20 a b$ \\
\hline FW & $7.94 \mathrm{a}$ & $7.18 a b$ & $7.43 a b$ & $6.39 \mathrm{~b}$ \\
\hline FWd & $26.75 \mathrm{a}$ & $25.59 a b$ & $25.72 a b$ & $24.09 b$ \\
\hline $\mathrm{FT}$ & 16.79 a & $17.07 \mathrm{a}$ & $17.43 \mathrm{a}$ & $16.08 \mathrm{a}$ \\
\hline KWd & $19.02 \mathrm{a}$ & $17.54 \mathrm{~b}$ & $17.84 a b$ & $16.52 b$ \\
\hline KT & $11.92 \mathrm{a}$ & $11.88 \mathrm{a}$ & $12.11 \mathrm{a}$ & $11.03 \mathrm{a}$ \\
\hline $\mathrm{AFL}$ & $57.44 \mathrm{a}$ & $62.77 \mathrm{a}$ & $63.80 \mathrm{a}$ & $56.05 \mathrm{a}$ \\
\hline BDAF & $42.54 \mathrm{~b}$ & $46.02 \mathrm{a}$ & $47.07 \mathrm{a}$ & $43.09 a b$ \\
\hline ADAF & $30.01 \mathrm{~b}$ & $32.14 \mathrm{a}$ & $35.09 \mathrm{a}$ & $33.19 a$ \\
\hline
\end{tabular}

Means followed by the same lowercase letter in the line do not differ among themselves by the Tukey-Kramer test $(\mathrm{P}<0.05)$.

Table 5. List of the first 15 selected genotypes according to BLUP of the genotypic values and the selection gain (GS) for the traits total weight (TW), accessory fruit weight (AFW), fruit weight (FW), fruit length (FL), fruit width (FWd), fruit thickness (FT), kernel weight $(\mathrm{KW})$, kernel length $(\mathrm{KL})$, kernel width $(\mathrm{KWd})$, kernel thickness $(\mathrm{KT})$, accessory fruit length (AFL), basal diameter of the accessory fruit (BDAF), apical diameter of the accessory fruit (ADAF), titratable acidity (TA), total soluble solids (TSS), and total soluble solids and titratable acidity ratio (TSS/TA), evaluated in growing environments of common cashew tree in Piracuruca, Barro Duro, Teresina, and Ipiranga do Piauí, PI, Brazil

\begin{tabular}{|c|c|c|c|c|c|c|c|c|c|c|c|c|c|c|c|c|}
\hline \multirow{2}{*}{$\begin{array}{l}\text { Traits } \\
\text { TW }\end{array}$} & \multicolumn{15}{|c|}{ Genotypes selected } & \multirow{2}{*}{$\begin{array}{c}\text { GS (\%) } \\
38.35\end{array}$} \\
\hline & $115(I)$ & $92(T)$ & $22(P)$ & $49(P)$ & $125(I)$ & $108(I)$ & $83(B)$ & $110(I)$ & $59(B)$ & $90(T)$ & $38(P)$ & $103(I)$ & $120((I)$ & $37(P)$ & $42(P)$ & \\
\hline AFW & $115(I)$ & $92(T)$ & $125(I)$ & $49(P)$ & $22(P)$ & $83(B)$ & $108(I)$ & $37(P)$ & $90(T)$ & $103(I)$ & $110(I)$ & $120(I)$ & $59(B)$ & $38(P)$ & $42(P)$ & 35.28 \\
\hline FW & $38(P)$ & $92(T)$ & $59(B)$ & $105(I)$ & $108(I)$ & $110(I)$ & $115(I)$ & $18(P)$ & $120(I)$ & $31(P)$ & $48(P)$ & $103(I)$ & $78(B)$ & $22(P)$ & $100(T)$ & 2.58 \\
\hline $\mathrm{FL}$ & $40(P)$ & $108(I)$ & 39(P) & $115(I)$ & $92(T)$ & $110(I)$ & $100(T)$ & $120(I)$ & $51(B)$ & $66(B)$ & $9(P)$ & $78(B)$ & $105(I)$ & $28(P)$ & $31(P)$ & 5.99 \\
\hline FWd & $38(P)$ & $105(I)$ & $115(I)$ & $108(I)$ & $120(I)$ & $78(B)$ & $48(P)$ & $91(T)$ & $92(T)$ & $9(\mathrm{P})$ & $31(P)$ & $100(T)$ & $18(P)$ & $110(I)$ & $103(I)$ & 4.28 \\
\hline FT & $83(B)$ & $103(I)$ & $59(B)$ & $105(I)$ & $36(P)$ & $14(P)$ & $75(B)$ & $22(P)$ & $32(P)$ & $92(T)$ & $108(I)$ & $95(T)$ & $115(I)$ & $64(T)$ & $120(I)$ & 2.12 \\
\hline KWd & $108(I)$ & $38(P)$ & $115(I)$ & $110(I)$ & $51(\mathrm{~B})$ & $92(T)$ & $120(I)$ & $48(P)$ & $40(P)$ & $7(\mathrm{P})$ & $96(T)$ & $59(B)$ & $41(P)$ & $31(P)$ & $116(I)$ & 2.46 \\
\hline $\mathrm{KT}$ & $83(B)$ & $5(P)$ & $36(P)$ & $45(P)$ & $59(B)$ & $116(I)$ & $18(P)$ & $22(P)$ & $112(I)$ & $104(I)$ & $120(I)$ & $82(B)$ & $103(I)$ & 69(B) & $6(\mathrm{P})$ & 1.60 \\
\hline AFL & $39(P)$ & $115(I)$ & $55(B)$ & $108(I)$ & $74(B)$ & $66(\mathrm{~B})$ & $92(T)$ & 99(T) & $38(P)$ & $103(I)$ & $107(I)$ & $120(I)$ & $110(I)$ & $22(P)$ & $34(P)$ & 15.35 \\
\hline BDAF & $115(I)$ & $83(B)$ & $110(I)$ & $49(P)$ & $112(\mathrm{I})$ & $22(P)$ & $119(I)$ & $71(B)$ & $103(I)$ & $107(I)$ & $38(P)$ & $37(P)$ & $59(B)$ & $50(P)$ & $90(T)$ & 8.16 \\
\hline ADAF & $113(I)$ & $52(\mathrm{~B})$ & $78(B)$ & $112(I)$ & $49(P)$ & $83(B)$ & $58(B)$ & $37(P)$ & $115(I)$ & $102(I)$ & $90(T)$ & $81(B)$ & $103(I)$ & $107(I)$ & $105(I)$ & 6.10 \\
\hline
\end{tabular}


In ranking of the 15 genotypes selected by BLUP, the individual highlights were genotypes 115, 110, 108, 103 from the municipality of Ipiranga do Piauí, 92 from Teresina, and 38 from Piracuruca, which showed superior performance for most of the fruit, kernel, and accessory fruit traits. Nervertheless, the selection should be practiced with caution, because the absence of an experimental design and only one year of evaluation, and mainly the target trait fruit yield was not directly assessed.

Genotypes 110 and 103 were selected for the total soluble solids/titratable acidity ratio, which also appear in selection of the fruit, kernel, and accessory fruit descriptors, showing the difficulty in joining all the desirable traits in a single plant. This performance is evident when comparing the individuals that stood out in relation to the physicochemical descriptors and those in regard to fruit, kernel, and accessory fruit. Paiva et al. (2005) also report difficulties in finding a plant with good phenotypic performance for plant architecture and nut production because plants do not always provide kernels with quality for sale and plant architecture/size that eases harvest of production.

Plants 124, 112, and 119 showed a high genetic effect for total soluble solids, and individual 124 was prominent with 20.75 oBrix. These genotypes selected for total soluble solids were sampled in the municipality of Ipiranga, which can be explained by planting of nuts originating from plants selected for the trait.

Plants 31, 74, and 118 stood out for titratable acidity, with genotype 31 from the municipality of Piracuruca, 118 from Ipiranga do Piauí, and 74 from Barro Duro. This selection is correlated with the phenotypic and genetic effects for the environments (Tables 2 and 4). In Teresina, the lowest phenotypic effect was obtained, and no genotypes stood out in selection. The genotypes 109 and 47 stood out for total soluble solids/titratable acidity, with genotype 109 from Ipiranga do Piauí, and 47 from Piracuruca.

The selected genotype 115, from the municipality of Ipiranga do Piauí, exhibited superior performance for most of the traits.

\section{REFERENCES}

Alves R, Bezerra FC and Abreu FAP (1999) Development and maturation of the apple of early dwarf cashew tree CCP-76. Acta Horticulturae 485: 255-30.

Barros LM, Paiva JR and Cavalcanti JJV (1999) Recursos genéticos de cajueiro: situação atual e estratégias para o futuro. In Queiroz MA, Goedert CO and Ramos SRR (eds) Recursos genéticos e melhoramento de plantas para o Nordeste brasileiro. Embrapa Semiárido, Petrolina, Embrapa Recursos Genéticos e Biotecnologia, Brasília, p. 568-589.

Cavalcanti JJV, Pinto CABP, Crisóstomo JR and Ferreira DF (2000) Análise dialélica para avaliação de híbridos interpopulacionais de cajueiro. Pesquisa Agropecuária Brasileira 35: 1567-1575.

Cavalcanti JJV, Pinto CABP, Crisóstomo JR and Ferreira DF (2007) Genetic control of quantitative traits and hybrid breeding strategies for cashew improvement. Crop Breeding Applied Biotechnology 7: 186-195.

Cavalcanti JJV and Resende MDV (2010) Seleção precoce intensiva: uma nova estratégia para o programa de melhoramento genético do cajueiro. Revista Brasileira de Fruticultura 32: 1279-1284.

Cavalcanti JJV, Santos FHC, Silva FP and Pinheiro (2012) QTL detection of yield-related traits of cashew. Crop Breeding Applied Biotechnology 12: 60-66.

Cruz CD (2013) GENES - A software package for analysis in experimental statistics and quantitative genetics. Acta Scientiarum 35: 271-276.

Cruz CD, Regazzi AJ and Carneiro PCS (2004) Modelos biométricos aplicados ao melhoramento genético. Editora UFV, Viçosa, 480p.

Falconer DS (1981) Introdução à genética quantitativa. Editora Imprensa Universitária, Viçosa, 279p.

Guanziroli C, Souza, HM, Valente Júnior A and Basco CA (2009) Entraves ao desenvolvimento da cajucultura no Nordeste: margens de comercialização ou aumentos de produtividade e de escala? Revista Extensão Rural 16: 96-122.

Henderson CR (1984) Applications of linear models in animal breeding. University of Guelph Press, Guelph, 462p.

IBPGR (1986) Cashew descriptors. International Board for Plant Genetic Resources (Bioversity International), Rome, 33p.

Instituto Adolfo Lutz (2008) Métodos físico-químicos para análise de alimentos. $4^{\text {th }}$ edn, Instituto Adolfo Lutz, São Paulo, 1020p.

Lima ESL, Silva EG, Neto JMM and Moita GC (2007) Redução de vitamina C em suco de caju industrializado e cajuína. Química Nova 30: 1143-1146.

Littell RC, George AM, Walter WS, Russell DW and Oliver S (2006) SAS for mixed models. SAS Institute Inc, Cary, 834p.

Maia MCC, Resende MDV, Paiva Jr R, Cavalcanti JJV and Barros LMB (2009) Seleção simultânea para produção, adaptabilidade e estabilidade genotípicas em clones de cajueiro, via modelos mistos. Pesquisa Agropecuária Tropical 39: 43-50.

Paiva JR, Barros LM, Cavalcanti JJV, Lima AC, Corrêa MCM, Melo DS and Porto ZB (2005) Seleção de clones de cajueiro-anão precoce para plantio comercial no município de Aracati, CE. Revista Ciência Agronômica 36: 338-343. 
Paiva R, Resende MDV and Cordeiro ER (2002) Índice multiefeitos e estimativas de parâmetros genéticos em aceroleira. Pesquisa Agropecuária Brasileira 37: 381-388.

Rabbani ARC, Silva AVC, Muniz EN, Lédo AS and Quirino ZBR (2012) Diversidade genética entre cajueiros comerciais. Scientia Plena 8: 1-9.

Resende MDV (2002) Genética biométrica e estatística no melhoramento de plantas perenes. Embrapa Informação Tecnológica, Brasília, 975p.

Resende MDV (2007) Matemática e estatística na análise de experimentos e no melhoramento genético. Embrapa Florestas, Colombo, 561p.

Resende MDV and Duarte JB (2007) Precisão e controle de qualidade em experimentos de avaliação de cultivares. Pesquisa Agropecuária Tropical 37: 182-194.

Santos AM, Rosado SCS and Oliveira NA (2014) Estimation of genetic parameters and verification of early selection efficiency in baru
(Dipteryx alata). Crop Breeding Applied Biotechnology 14: 238-243.

SAS (2008) Statistical analysis system user's guide. Version 9.2. Statistical Analyses System Institute, Cary.

Silva SS, Pordeus RV, Pereira JO, Dantas Neto J and Bezerra JM (2013) Estimativa de parâmetros genéticos do cajueiro anão precoce em um solo arenoso pelo procedimento REML/BLUP. Revista Verde 8: 41-51.

Silva SS, Pordeus RV, Marques GV, Cunha EM, Pereira JO and Azevedo MRQA (2012) Caracterização genética do cajueiro anão precoce no sertão central do Rio Grande do Norte sua predição pelo procedimento REML/BLUP. Revista Agropecuária Científica no Semiárido 8: 07-19.

Wald A (1943) Tests of statistical hypothesis concerning several parameters when the number of observations is large. Transactions of the American Mathematical Society 54: 426-482. 